\title{
From the Mystical Unity to the Pantheism (Oneness of Existence)
}

\author{
Fatemeh Hakima $^{1}$, Naser Moheseni Nia ${ }^{2}$, Mohammad Shafi Saffari ${ }^{2} \&$ Syed Esmail Ghafelehbashi ${ }^{2}$ \\ ${ }^{1}$ Persian Language and Literature, Subject of Gnosis, International University of Imam Khomeini, Qazvin, Iran \\ ${ }^{2}$ Department of Persian Language and Literature, International University of Imam Khomeini, Qazvin, Iran \\ Correspondence: Fatemeh Hakima, Persian language and Literature, subject of Gnosis, international university \\ of Imam Khomeini, Qazvin, Iran. E-mail: Fhakima@gmail.com
}

Received: January 21, 2016 Accepted: February 16, 2016 Online Published: March 31, 2016

doi:10.5539/jpl.v9n2p64 URL: http://dx.doi.org/10.5539/jpl.v9n2p64

\begin{abstract}
In the gnostic literature of Iran and in the Islamic Gnosis, gnosis has been interpreted as an effort to save the individual by accessing to the real unity.

The unity, mystical journey (conduct) and the relation of God with creature are considered as three main axes under the theme of unity or the gnostic unity until before the pantheistic gnosis of Ibn Arabi, the concept's explanation and the definition of unity in terminological and lexical terms, expression of unity concept in the non-Islamic gnosis, explanation of unity concept in the Iranian-Islamic gnosis until the period of Ibn Arabi, expression of the way of mystical journey, explanation of mystics' attitude on the subject of mystic unity based on the belief of Gnostics of Khorasan school, expression of God's relation with creature in the Iranian and Ibn Arabi's gnosis are considered as the most fundamental under considering instances of this research work; in addition, a brief explanation on pantheism of Ibn Arabi is also under consideration. The theoretical pillars of exalted unity from the perspective of Ibn Arabi, are existence, entity and manifestation; Ibn Arabi, contrary to his preceding Gnostics doesn't consider the creatures mirageor hallucination. This view is somewhat different from the views of mystics of Khorasan, and Gnosis of Khorasan, the differences that have led to two ways of Conduct (Mystical journey) in gnosis. The scope of this research begins from the third century AD and continues by the end of the seventh century that is the rise of theoretical gnosis based on the Ibn Arabi's pantheistic opinions.
\end{abstract}

Keywords: mystical unity, gnosis of Khorasan and Iraq, pantheism, conduct or mystical journey of Ibn Arabi, relationship of God with Creature

\section{$>$ Mystical Unity from Third Century to the Period of Ibn Arabi}

The mystical or the mystic unity in the Iranian and Islamic mysticism has been shaped from the very beginning of the third century based on the three principles: 1-unity 2-conduct/mystical journey and 3-relation of God with creature and gradually, it has continued its way of evolution. In this section we are seeking to explain the story of mystic unity in the Iranian-Islamic gnosis to the era of Ibn Arabi and we would follow it by explaining the three principles mentioned above.

\section{a) Unity}

Thinking about the Creator of existence, is one of the most important part of thinking and reflecting of man from the beginning of his creation until our time and will further continue likewise.

The sons of Adam, of any gender and race, from any religion and language and at any intellectual and scientific levels, at any age and time as well as in any location have ventured to think as much as possible and not to their needs about the origin and root, the Lord of essences and creator of being using diverse methods and ways, the most important way that was more lasting, the rational and illuminating ways of thinking can be named in this respect.

This thought and its persistence narrates a persistent need for people, because thinking about the first origin is considered as human natures. Just why the Islamic mysticism is also defined and interpreted in a word as an attempt to save the individual by achieving "real unity." (Bertels, 1356: 74) and undoubtedly, this issue although its purest ideas and thoughts are related to the Islamic mysticism, but it is so serious and significant that in the world viewing of all mystic schools and even in the non-Islamic semi mystic schools it exists with some differences. Despite all differences and distinctions that exist in the mystic schools of the world and despite all 
differences in its interpretation, all these schools are based on the similar and sometimes identical principles and issues. Yahiya Yasrebi in his book on theoretical gnosis has considered the common instances of various global gnosis in the six following points: unity, vision, mortality, austerity, love, secret and mystery (Yasrebi, 2012, 124). Also, "Stacey" the English researcher and scholar of mysticism, "says: unity or unit is the focusing experience and sense of all different mysticism." (Stace, 1979: 84) and perhaps because of the abundance of the notion of unity or unit, the mysticism and Iranian gnosis have been shaped by theoretical discussions from the very beginning and the sparks of pantheism can also be seen across the basics of Iranian mysticism.

Of course, the definition of "unity" because of the words' pragmatism is definitely something impossible or difficult, because essence is pragmatic matter and the definition of essence is obviously nothing more than a definition of noun. But at the same time efforts have been made to present the definition of "unity". For example, Baghli Shirazi considers the unity as disengagement of heart from contingency to the visibility of timeless eternity. (Baghli Shirazi, 1996:567) or Mostamly Bukhari in his valuable book of "an account to Recognition of Klabazi" in defining the Unity chooses the theological way and says: " Unity wisdom is in that you recognize him by attributes and know that God is one and you identify it with the attributes of Ever Living, Knower, Seeker, Mighty, Speaker, Hearer and Seer and such person is Gnostic Because he has realized the truth or reality of his knowledge, that is the cognition of his essence and characteristics. The meaning of God's Oneness is that you separate the others from him both characteristically and intrinsically and see nothing other than him."

Islamic Gnostics have recalled the theme of mystical experience of unity from the second century AD onwards first under the titles such as mortality and later under the more perfect title of mortality that is the thing which has been interpreted as 'union with god' in the Christian mystic and finally under the title of 'mystical union.' (Kakaei, 2013:108)

In fact, the Islamic mystic experiences started from the proximity feelings and ended to the plurality, unity and Oneness that is the very mortality. Unity is the highest degree of proximity and it is not irrelevant that Abu Saeed Aerabi said: There is no being closing to God, because if this is the case, we believe in the distance "(Esfarayeni, 1980: 94)

Khwaja Abdullah Ansari says: "proximity is duality that one was close to other, thus when you look accurately, then proximity would be remoteness, mysticism is Oneness (unity=union). (Ansari, 1993:127)

The discussion of love and knowledge are closely associated with mystical vision of unity, yet the love is more highlighted in visionary mysticism but in the existential gnosis, the discussion of knowledge sounds more colorful, love is more about gnosis and separateness unity but We in the knowledge and the knowledge way in addition to noticing the love, we also notice the mysticism and extroversive unity. As another example, Syed Yahiya Yasrebi in his mysticism book says:

Essence is a sole truth that is pure of any division and multiplicity in its inside with its perfect unity. (Yasrebi, 2013: 174).

\section{b) Conduct/Mystical journey}

Gnostics after paving the route to unity and traveling the levels make effort to see the unity with entity, the unitarian gnostic starts his internal course to the One and tries to find way from the linguistic Oneness stage to the stage of Practical monotheism. From the beginning of recorded and documented human history to date, we've had hundreds of thinkers and distinguished thinkers, each of them had sometimes varying approaches and attitudes towards the world and essence/existence, approaches and attitudes of each of them has been different such as their behavioral actions, yet, it doesn't mean the absence of a similar attitude among the majority of these mystics. But we widely observe that the conduct of a number of this precious collection is closer and similar to each other in terms of type. The type of conduct and attitudes of Bayazid Bastami (d. 224 AH), Hussein bin Mansur Hallaj (d. 309 AH) and Faridduddin Attar Nishabouri (d. 618 AH), with all the strength and weaknesses that exist near them; can be set to a same range and class. On this base, their Ideational scope is assessed identical. And the existence of these similarities and resemblances caused the thinkers of Iranian-Islamic gnosis area, divide the Iranian group of Gnostics into two groups of Khorasan and Iraq Gnostics; of course, it is important to explain this point, that this division contrary to its name, doesn't have geographical sense in its conventional and famous sense rather it has the intellectual and spiritual concept of it i.e. those whose ideational realm of mysticism is close to the gnosis of Khorasan's Gnostics and those whose ideational domain, attitude and conduct is close to the mystics of Iraq. (Shafiei Kadkani, 2014: 87)

On the other hand, since, the beliefs, thoughts and attitudes comprise the infrastructure as well as intellectual, attitudinal geometry of people, the beliefs and attitudes that all in all we interpret them as our world view, is that 
specific worldview which is the basis for the attitude and behavior of human essences. In such a way that acceptance and continue to believe them motivate that the person who has adopted the certain attitude and belief, would show a temperament appropriate to that belief and attitude and if probably for any reason, he gives up that attitude and belief or retreats from it, undoubtedly by the passage of time he would lose that temperament. With this description, it is clear that the proportion of world viewing and thought with behavior and practice is considered the needs of a coherent and targeted ideology. Abundant emphasis of holy Qur'an and prodigious stress of Prophet (PBUH) for the need to change the thoughts and reforming the world viewing and the beliefs of people and inviting them to Monotheism and rejecting the polytheism and idolatry as well as arrogance are assessed from the same category. Attention to behavioral actions and the type of conduct by Gnostics are also significant for more accurately defining the theme of unity. In this regard, attention to the specific language of Sufis and mystics is also necessary because we can understand their beliefs and attitudes as well as the way of their conduct through such linguistic elements left by Sufis and Gnostics and through the same linguistic elements we will understand their way of conduct/mystical journey and way of their look to the topic of mystical unity.

\section{c) Relation (Attachment) of God and Creature/Creation}

Following the discussion of the issue of the unity that is a common delicate pointer among all religions and gnosis, the next important point is the expression of creature/creation and its relationship with God in the framework or scope of divine affairs and undoubtedly, the solution of this important issue simplify the issue of Unity. The union of God and the manner of relation between the sole Creator and the multiple creatures will be investigated and researched in this regard to make the understanding of unity topic easier. The unity issue and the love between Pre-eternal Sole and Creature have been put to analysis by the speculative theologians, Gnostics, interpreters, and philosophers. In this issue we further discuss the statements of Mystics that is unique in its kind; something that has not been done so far in none of the books and articles and theses or even in scientific-research articles related to the Persian literature discipline. By analyzing the above themes, we see a clear gap between the two groups of mystics, the mystics of Khorasan and Iraq and our work in this paper is to explain the belief theory of Khorasan Gnostics that is explainable and depict able through their statements/sayings and behavioral actions.

The meaning of Khorasan and Iraq gnosis as mentioned before, is not merely the environment and geographical climate, because for example, Hallaj was a native of Gulf, but by our supposition in terms of theory such as the mystics of Khorasan, he is considered to be among them, and the opposite of it is also true. For example, we consider Khwaja Abdullah Ansari from the mystics who desire the thought of gnostic tradition of Iraq and he is from a class of discussion and debate rather the family of spiritual discovery and combat while he is Heravi from the origin of Heravi. Of course, these two expressions are not much different conceptually, but have developed two different views that end in distinct conductive ways. Khorasan mysticism should depart under the first way that only comes from the struggle with self, i.e. Red death. And under the second method, the seeker should access the existential knowledge that is provided by unveiling/discovery, learning and debate associated with intellect. Perhaps the Pantheism could be expressed by an allegory that is: the essences have known the existence in human form that every word he utters is alive until he is a living creature and perhaps this example is a closest instance that makes the divine breath comprehensible where the creatures are all word whose remains survive as long as he blows his breath over them consecutively," And we have rightly comprehended that the survival is in the form of things which are created and it is nothing but the blood or breath, somewhere he says: and when I processed the human essence and blew my breath/soul in him, and that is the same breath that God resurrected the faith by its existence and then revealed it" (Ibn Arabi, 1405; third book, Volume 9: 90) and we see the divine breath in the ascent arch is the best form and in the descent arch it is along with the same creatures but it is their entity because God says: "I am closer to you more than your jugular vein." "Therefore the truth of Mohammedia (s) consists of two semicircles: it means, ascends in an arch from the point of Unicity/Unity with objective validity at the time of hiddenness and in other arch, reaches the Unicity point at the time of appearance. In this arch, as much as the ascent and descent are in closer form, they are farther from the unity truth. Because the truth of oneness of Allah is the meaning of all meanings and truth of all facts" (Yasrebi, 2013: 342) world is in the form of circle under the descent and ascent arches that is not empty of entity but it is the entity itself and at this stage Mohi-ud-Din says: essence is God / Creation. It is from the countenance of God not from the countenance of Creation.

Opposite to that, Attar as one of the greatest representative of Khorasan gnosis says:

$1-" W h e n$ you come out of the existence's thought-Whole existence revolves around you like a compass 
2-If you in the thought of existence don't worry- inexistence gives nothing at hand"

(Attar, 2010: 298)

While Abu Nasr Sirraj (demise: 929 AD) says: "your existence is sin itself (Schimmel, 1996:251) or this phrase of Junaid: "God is more acknowledged by inexistence rather by existence" (Ibid 324) some type of difference (pass the way) is seen in two schools of Khorasan mysticism and mysticism of Mohi-ud-Din.

In expressing this class, the Khorasan gnosis is the existence against egoism; however the expression of Ibn Arabi is something different. He considers the essence as the only reason of slave's originality. That is how we are dealing with two different mystical styles that can be divided into the pre and post Mohi-ud-Din mysticisms. Close to what they say are the mystical style of Khorasan and the mystical style of Iraq where Mohi-ud-Din is the outstanding mystical figure of Iraq. In other words, the mysticism of Khorasan means withdrawal from the self, in this migration, the seeker achieves the proximity of God and in the gnosis of Ibn Arabi the extremity of conduct is to reach the point of knowledge that the seeker should find this delicate pointer with unitary vision that God is the creature's entity and duality has nothing to do with it. In other words, reaching the extremity is the self-recognition because "anybody who recognizes himself has identified the God. Therefore, the seeker is not sent out but by identifying the depth of his existential self, understands the secret of unity, at this moment he sees the two sides of coin as God and creature; the speech that Ibn Arabi abundantly relies on and believes in it. He says: Know yourself and know the truth/God. "(Ibn Arabi, 1405, Vol. 4: 217)

Understanding the pantheism, or in other words the self-recognition, in the gnosis of Ibn Arabi is the extremity of spiritual journey. Seeker to God, at the beginning of conduct, has no knowledge of himself and consequently no knowledge on God but consequently the conduct makes 'knowledge of self' of its own and realizes that there is nothing but God. (Shajari, 2011: 130)

Unity of vision: this should be expressed first that as per the research of writers the term of vision unity has been used under its raw and initial meaning for the first time in the works of "Ahmad Sir Hindi" died in $1050 \mathrm{AH}$ and before him we don't see such combination in Iranian Gnostics and Muslim mystics' works, although Ahmed Sir Hindi too, while using this term, had no modern interpretation of it. In fact, the use of this term in its common and modern sense is rather made up by western orientalist, "Phone Creamer", the concept that has gradually become common among knowledgeable people. (Kakaei, 2013:117)

Anyway, those who maintain the "unity of vision" believe that when the aspirant of God reaches this portfolio/status knows all names and attributes amortized in the Unseen/invisible world of Unity Essence and except observing the Unity Essence no set up remains in his soul and strangers have been eliminated from every direction and then the smooth and pure monotheism has been emerged and realized and at this time and place he uses the mystics' tongue "Oh God Oh God there is nothing and no one except you. "Unity of vision" may also be known as the present and the interpreter of seeker that would have reached the state of immortality and eternity, the believers of unity of vision, believe that not finding or not seeing the multiplicities is not the evidence on their absence and the lack of entity for other than God is not the evidence on someone other than God. (Ibid 117)

Perhaps for this reason many of the mystics and especially Ibn Arabi, do not believe in the separation of "Pantheism" and "Unity of vision" because, basically science and known/datum are united and associated with each other in the verbal and visionary science. Therefore, verbal knowledge is unmistakable. In other words, there is unity between ecstasy and existence, because the ecstasy and conscience of perfect mystic, is nothing but existence and in it, the threshold of, to find, found, finder and has been found, have no separation from each other, though some mystics have not shown any agreement with this outlook, and have accepted and admitted some of the differences between two categories of "Pantheism" and "Unity of vision" and the following instances can be referred to from such differences.

\section{1- Unity of vision and /or Annihilation of Creature}

is the state or portfolio that as per the beliefs of Gnostics, they observe nothing except God in this state, whereas the pantheism, despite it comes out from mystical experiences but it is basically the belief of cognitive and theoretical essence under the 'chapter of essence' that relates to thought and faith.

\section{2- Content and concept of vision unity}

The unity of vision is that the gnostic has seen nothing except God, while the concept of pantheism is that no essence exists except God, the metaphor that can be referred to for vision unity, is the disappearing of real light of stars at the sun rise.

But the interpretations that are used for pantheism include shadow, indicator, mirror and the face holder that 
express the relation of real and virtual matters (not the relation in real affair). (Ibid 118)

Each of the Gnostics of vision unity is also different in some ways. For instance, the visionary mysticism of Hallaj leads to a kind of anthropology and from this direction it closes to the gnosis of Ibn Arabi and this is why some people have assessed the gnosis of Hallaj as the existential gnosis. But the gnosis of visionary unity for the most mystics of Khorasan still remains the pure visionary unity. Like the mysticism of Attar, he gave the originality to truth/reality. German orientalist Helmut Ritter has realized this delicate pointer in his book. "Sometimes a gnostic thinks that he looks only God everywhere. Sometimes he sees only himself. As a result, one does not know whether he is dealing with some kind of mystical theology or some kind of anthropology. (Ritter, 2010: 360) The Khorasan mystics whose conductive movement lies on the base of combat against Self and Red death, surly belong to visionary unity and see the universe like a pyramid that has only one summit and nothing more. And the cones' bases are fictitious and imaginary. In other words, the mentioned Gnostics have added the multiplicity with unity, the addition that is dominant to the unity and the addition resultant of each number in zero is the same number. For this reason, Attar has not spoken much on unity and multiplicity. Attar locates the slave in the place of bondage and the right to its right place and says:

"All that you want to say of him, say to him-All that you look for about him, find from him"

(Attar Nishabouri, 2010: couplet 2791)

The human cognition on his surrounding world and his special place in the existential system would have great impact on the actions and lifestyle of him. The life quality of mystics on one hand and the manner of humans conduct without the correct outlook on world viewing in the history of human societies on the other hand, show the influence of unitary ideas in the character and behavior of each individual. However, the conduct of unitary Gnostics also has the significant differences; from the ideational perspective its solution is Unitarian. Bubbles like look at the world or even the existential look to the world are two great monotheistic ideas that have benefitted the two general visionary and existential ideas.

\section{Ibn Arabi and the theory of Pantheism}

Ibn Arabi (d. $628 \mathrm{AH})$ is the greatest Gnostics of Islamic world and the founder of theoretical gnosis who added several discussions to the Islamic gnosis by his considerable ingenuity: " He is a genius for ordering the mystic thoughts and theories rather than a God intoxicated holy man/fascinated mystic and introduced a comprehensive and coherent system of mystical thought for his later generations." (Schimmel, 1996: 443) The Pantheism theory, the main constitution of Ibn Arabi's thought is based on it is included in the theories that probably have long background in the history of human thoughts. "The pantheism issue/question was firstly discussed by Muslims and specifically by Ibn Arabi (d. 638 AH)" (Motahari, 1991, Volume 1: 216). . However, some believe that others have also pointed to pantheism before Ibn Arabi (Javadi Amoli, 1996, Vol. 10: 491). What was before him, the pantheism or the unity of vision, the experts are not of the same pinion in that (Motahari, 1991: 210). However, Mohi-ud-Din is the first who used the interpretation of "pantheism" as the precise meaning of the word (Afifi, 1992: 25) and all consider Ibn Arabi the inventor/forger of "particular unity" theory. Ibn Arabi is the most outstanding and most powerful preacher of pantheism in the Islamic world "(Movahhed, 2011: 142). Theory; is the mega words of every epoch-maker and pantheism is the constitution of intellectual system of Ibn Arabi. Since the "Quran verses constitute the infrastructure of all mystical/gnostic doctrines" (Schimmel, 1996: 72). There are several verses in the holy Qur'an that suggest the pantheism in the mind: "so anywhere you turn there is the manifestation of God" (holy Qur'an verse 2: 116) or the verse "He is the first and last, exoteric and esoteric." (Ibid, verse 4:75). Ibn Arabi himself in his books, names the previous mystics and Sufi masters including Marouf Karkhi (d. 200 AH.) and says: the sentence "there is no one in the existence but God" has been affiliated to him for the first time (Kakaei, 2012:148) we point out that the epoch making persons are the abstract knowledge of their time. They benefit from all existing heritages of culture and knowledge. Ibn Arabi is not exempted of this rule; too "he melts and transforms the existing data of his previous culture in his artistic and spiritual systems with the alchemy of his imagination and as a result this alchemy of each data, finds the sense and special shades of it and it is totally different of what it had before entering this system." (Shafiei Kadkani, 2014: 546) Ibn Arabi has made his own mystical attitude by believing in the theory of pantheism and by scrutinizing in the Bezels and Mystical unveilings, this meaning completely becomes evident. The verses of holy Quran, prophetic traditions and sayings of great scholars and mystics in his intellectual system with a pantheistic look are interpreted so artistically that is really astonishing. Ibn Arabi uses an interpretive language. Nicholson by describing the style of Ibn Arabi says: "Ibn Arabi extracts a verse from verses or a tradition from the traditions of prophet, and interprets it using the prevalent method used in the writing works of Jewish Philon." (Ibn Arabi, 1988:12) He does not argue but interprets. Also, the nature of religion is paradoxical and persuasion, 
and in fact, it is the base of discursive people in the area of the wooden religion; because the theological issues are not arguable in nature, one accepts or rejects it. Is what they say: Faith is nothing but accepting by heart. (Bahar Nejad, 46: 2008) Thus, if sometimes the expression of Sheikh is associated with contradiction it goes back to the nature of the base that he explained and glossed by him as the God is also esoteric concurrently when it is exoteric. "God is First and Last, as well esoteric and exoteric." And also God is closer to us than our jugular vein and concurrently based on the tradition of holy prophet:" undoubtedly, the devil is running in human veins as blood flows" that unfolds the comparison of dual structure of God vs. Satan. Similarly, the almighty God manifests in his names as well as contradictory and diverse attributes, the manifestation of glory of God and the manifestation of his mercy and compassion that is enveloped at the same time in the individual essence of an astonishing unity. For this reason, Ibn Arabi considers the "intellect as inefficient to understand the issue of Pantheism because he considers 'negative and affirmative judgments' at the same time as absolute impossible matter such as the objectivity and diversity of God's names in relation to God" (Rahimian, 2013: 23). The delicate pointer of existence is not unveiled by direct and single procedure look. Ibn Arabi considers the understanding of the mysteries of the universe - pantheism just possible for the mortals of Divine threshold. The delicate pointer if someone comprehends it has reached the mortality stage. In this paper, we speak of Pantheism. Pantheism consists of two obvious words, essence and unity while both words are undefinable ${ }^{1}$ (essence is an obvious matter and the definition of some entity is nothing more than explaining a name). Essence is one of the key discussions in the gnosis of Ibn Arabi that is the most colorless words in the scope of philosophical thoughts. Pantheism from the very beginning aroused sensitivities and some like Ala'aedoleh Semnani (d. 736) knew it against the Oneness and monotheism. "However the followers of Ibn Arabi School, gradually dealt with its explanation and interpretation, and even some important interpreters of this mystical school during $8^{\text {th }}$ and $9^{\text {th }}$ centuries such as Ghesari (d:751 AD) in explaining and introduction of Bezels of Wisdom by Ibn Arabi and Syed Heider Amoli (d:787 AD) in his handbook of 'Jameol Abrar and Mambaol Anwar and especially in its summary, and Saenoddin Ali Bin Torka (d:836 AH) in the Tamhidol Ghavaed(preface to rules) tried to present arguments for intellectual and philosophical proof of this theory that of course these reasons also caused abundant philosophical conflicts (Souzanchi, 2005: 133) and in some instances, their analysis was not what the Sheikh has willed of pantheism. So, unity in the sense of confining the essence in God is the consensus of mystics "limiting of essence in God has been appeared in the works of Sufis/mystics from the very beginning (Maulavi, 1342-1336: 144). What makes the difference is that what is the relation of God with creature? Whether it is his entity, imaginary appearance, fantasy or mirage like appearance? Here is the gap between the views of sheikh with the opinions of mystics before him. Each theory is composed of structural look of basic comparisons. The mystical system of Sheikh has also been created of comparison between God and creature. One of the main objectives of this paper is to explain the same concept that what is the relationship between God and creature? Whether believing in such a theory is equal to negate any effort? And further that which faith was followed by mystics before Mohi-ud-Din? Further, what indications exist proving the pantheism of Ibn Arabi including the evidences that have been mentioned in the Bezels, is a verse that expresses the oneness of essence in the Bezel of Ishaqi.

"O God, you are the creator of things, you are perfect what you create, all that you created is unlimited and you are the source and origin of everything from large and small. "

(Ibn Arabi, 1988:88)

Jahangiri in explaining the above couplets says: "Ibn Arabi considers creatures like a wave on the infinite and roaring ocean and in explaining the second couplet regards the narrowness in terms of Unity and all-embracing in view of nominal manifestation and especially his manifestation in the name of All Embracer" (Jahangiri, 2005: 202)

In addition, Ibn Arabi in the Bezel of Ismaili expresses a suitable explanation based on his intellectual system: "No analogous exists in essence and no opposition is in essence, certainly the essence is a single reality and thing is never opposite to it."

Other evidence in the Hood's Bezel where he says: "as per the true news God is similar to things and things are limited though their limits and size are different" (Ibn Arabi, 1988: 111).

Same speech is repeated by Ibn Arabi in the Bezel of Noah: "God has a specific appearance in every creation and creature and God is evident in every concept." (Ibn Arabi, 1988: 68)

"Who are you running away from? There is no one in existence, is this right to ask whether he exists or that who is he? If you say: whether eyes consider this question ugly? "If you say: who and what is he? So there is no one except him." 
Jahangiri explains this couplet in this way: if from the direction of unity, you look to God you would observe the God. And anytime you see him from the multiplicity perspective you would see the creature i.e. it is creature in terms of nominal unity in the forms of individual essence and in view of intrinsic unity, that is God" (Jahangiri, 2005, 201).

It is also seen in Bezel of Nourieh wisdom: anyone we perceive him, so it is the real existence of possible individual essence. (Ibid 184)

Ibn Arabi everywhere in his two famous works has said that completely expresses his theory on pantheism, including: "God had been without anything with him", He is same right now, as was before. (Ibn Arabi, 1405, first book: 51). Glorified is the God who revealed objects while he is their entity, which is another interpretation of his own signification, and nothing out of him. Elsewhere Ibn Arabi says: "There is nothing in the universe that the eye can see it but the nature of that essence is God and what is seen is God not the creature" (Gheisari, 2005: 244). In addition, what can be perceived by each of the perceptive faculties' is the God's essence in the individual essences of possibilities (Ibid 244). So, the world has no extra existence over God. (Ashtiani, 2002: pp. 184-185) and finally the phrase the "Glorified is He who revealed things while he is their entity" (Ibn Arabi, 1405, IIbook: 459 ) that is the summary of his pantheistic theory. The base of this article is also on the same famous phrase that many people have excommunicated Sheikh by resorting it.

\section{Allegories of Sheikh to understand pantheism}

Ibn Arabi to explain the pantheism resorts to various instances and as the nature of his theory is absolutely conceptual and while through tangible and materialistic examples with clear contradiction, the accurate theme is not explained with allegory and metaphor, of course the Sheikh has not used it only for the poetical decoration because these virtual statements, make the readers more familiar with the theory of pantheism and cause approximation of mind and more familiarity; the method that has background in holy Quran. Pantheism is the essence of his theory, and the axis, his entire thought moves around it, he engages in finding the species of metaphor and allegory that has no benefit but making it more ambiguous and knotted and finally, this could be said on this analogy, that they are wrong comparison of two things with each other. (Afifi, 2008: 325) now we refer to some samples of allegories and metaphors.

1- Ibn Arabi expresses the symbol of numbers that appears from the various components of unit (one number) and different degrees of numbers. The amount of God's permeation in creatures is different in creatures in terms of the degree of manifestation and divine names. "So, the number in the computing numbers (countable)) is limited to the nature of Conditioner/Dominant and he has no entity, and manifestations in the outward forms and their multiplicity are dominant in one entity" (Ibn Arabi, 1405, Book V: 370) and says: "God is as making flow of number one, across other digits". Ibn Arabi has dedicated half of his "Ahadieh booklet" to this theme.

2- Other sample is the nature that Ibn Arabi examples it for the Pantheism. He says in the 'Idris Bezel': "as the faces of nature are diverse and multiple but different from each other, but the nature itself is single entity, this rule is also in practice between God and Creature, though God is one with abundant manifestations" (Ibn Arabi, 1988: 78).

3- One of the analogies he uses to explain the relationship of God and Creature is the metaphor of existential entity to mirror and the metaphor of plurality that is the very essence of possibilities in the forms that is reflected in the mirror. This metaphor is more accurate than other similarities due to the appearance sign. "This is a fresh metaphor but this is to be noted that it should not be under considered with all components and consequences, similar to all other metaphors; because such theory intrinsically does not fit within the framework of Allegory and materiality "(Afifi, 2008: 326).

4- From the other examples that Ibn Arabi expresses to show that God exists and has influence in all forms of essences and creatures, says: "Paint penetrates in a colored body so presentation is where there is essence, as God exists in the forms of creatures." (Ibid 186) (Ibn Arabi, 1405, Book I, pp. 486-461; and second journey: 16) Afifi says: "this is the speech the smell of incarnation reaches the taste; however in the religion of Ibn Arabi there is no place for incarnation. Therefore, we should understand these speeches as the virtual words." (Afifi, 2008:108) we read in the mystical unveilings that: "there is no incarnation and union and incarnation is a persistent disease and no one speaks of incarnation and union but the supporters of blasphemy" (Ibid181).

5- He says in another metaphor: "relation of single existential entity and different multiplex forms is like the relation that lies between the self of single person and its body where the forms of his organs are multiple. For example, Zed is a single reality but it is multiplex in the form of its parts and organs. Therefore, he is multiplex in unity or unity in plurality. "(Ibid 325) Therefore, these allegories and metaphors of Ibn Arabi cannot 
demonstrate an accurate picture of Pantheism's thought. Inevitably, the only way forward for understanding his theory is that we should deal the expression of his pantheism theory in view of his two great works, "Bezels" and "Mystical unveilings." Ibn Arabi is Unitarian and monotheist, he pointed out repeatedly in his works and says, "God doesn't belong to the genus of possibilities. Therefore, though, He is the Sublimation to the outward entity of the forms whatever the manifestations are on those forms and entities, but not from its generis because he is the Sublimity of the Necessary existent by itself, and manifestations and possibilities from eternity to eternity are necessarily non-existent by their selves: (Ibn Arabi, 1405, Book VII: 370). Blaming him of polytheism is the sign of lacking the true understanding of his theory on pantheism.

\section{Research Background}

Numerous studies and researches have been carried out on Pantheism; however, on the gnostic unity/mystic unity, no independent research has been made until the period of Ibn Arabi. Researches related to the pantheism are seeking the comparison of Ibn Arabi's pantheism with other issues including; comparative investigation on pantheism from the perspective of Ibn Arabi and Espinosa that the author with deductive look tries to conform Ibn Arabi to Espinosa (Hosseini Shahroudi, 2009: 129). Or considers Pantheism: experience, allegory and metaphor by Ghasem Kakaei, pantheism from the perspective of revelation where the author of it has considered the pantheism similar to Samadi Unity/All-rich related Unity and based on the assertion and approval of pantheism specifically, the theory and reading of Allameh based on the opinions and views of Allameh Rafiei Qazvini/Ghazvini aim to ascertain the pantheism (Roudgar, 2011:111). In addition, some articles have directly dealt with the pantheism of Ibn Arabi; so their results are as follows because of their more relation to the present paper.

The article of Akrami and Hemmati under the title of "pantheism and the unity of religions, 2011" concluded that Maulana Rumi, was one of them who were under the influence of Ibn Arabi and it is the real and single entity of that Lord while the outward creatures have a shadowy and subdominant existence. The author continues: the concept of influence of Ibn Arabi over Maulana has some contras, too. (Akrami \& Hemmati, 2011: p-104-106).

Other article under the title of "Ibn Arabi and the theory of Pantheism " by Zakarya Bahar Nejad in which the writer deals with the investigation of this subject by critical look that some people accept that the term of pantheism has not been used in the works of Mohi-ud-Din and he as well didn't believe this theory and this term was used by the interpreters and explicators of Ibn Arabi. The writer has proved using three ways that like this term were used in the works of Ibn Arabi and also he was a Pantheistic gnostic. Including that: Ibn Arabi has explained the term of Pantheism in his two booklets named: "Booklet of Sufism" and "Book of Wisdom" and in some other works he has used the term of existential unity in place of pantheism. (Roudgar, 2011: 111)

As expressed before, until the time of Ibn Arabi no independent and discussable research has been made on the gnostic unity. However, under the chapter of pantheism, despite abundant researches, no indication has been made to the dimensions of objectivity of the God's right for creature in any of the mentioned researches that has provided the gap among the views of Gnostics of Khorasan and the gnosis of Ibn Arabi. In addition to explaining that gap, the approval of the 'best system theory' and the persistent motion of existence have been dealt with in this article; although, the outcome of pantheism theory is investigable, but it requires a considerable opportunity. The researches related to the subject were read as far as possible in this manner. Present article is a further look to express the Pantheism of Ibn Arabi. In this essay, effort has been made to use the principle of "a part of original text is the interpreter of its other parts." Therefore, by relying on the harmonistic principle, by interpreting the text by text itself, we engaged in processing the theory of pantheism propounded by Ibn Arabi. Specifically, the language and method used by Mohi-ud-Din is explicative. If to understand the expression of Sheikh, we only benefit from the views of its interpreters and followers, we are dealing with the interpretation and gloss; besides, the explication of interpreter couldn't remain far from the filter of his taste and faith and get affected, up to some extent. Therefore, this might keep the researchers farther from the pantheistic meaning and sense that he meant.

\section{What is the theory of Ibn Arabi?}

To solve the problem of pantheism we refer to the famous statement of Sheikh: "Glorified and Pure is the God who revealed things, while he is himself their entity," the theory that is the essence of his thought in his all works and all interpreters and commentators have admitted it throughout the history as the backbone of his world viewing and ontology is the thing called pantheism and this pantheism has been summarized in the same phrase "Glorified and Pure is the God who revealed things, while he is himself their entity," where the comparison of God's right with creature is apparent. "Ibn Arabi has clearly expressed this phrase in several places of "Bezels and Mystical Unveilings": including where he says: therefore, glorified and pure is the God that revealed things 
while he is himself their entity" (Ibn Arabi, 1988:25 book II), (Ibn Arabi, 1405, book II: 604). We take the key to understanding this phrase from the speech of Sheikh and decode it as we believe the word of Sheikh is interpretive and multifold and have the strength to any interpretation and no better standard is available except the "Bezels" and "Mystical unveilings" as the great works of Sheikh, hence we deal with his two works of "Bezels" and "Mystical Unveilings." Alaeddoleh Semnani says: "When in the conquests of Macca I reached to the statement:" "Glorified and Pure is the God who revealed things, while he is himself their entity," I said to myself: the pronoun referral of "He "is not Divine essence, but its reference is not to be appeared that is extracted from the verb of "appeared" and the meaning of sentence is that: " holiness and purity is worthy of God that exposed the things to appear and this appearance is the entity of things." (Hosseini Shahroudi, 1387: 130). In the Bezel of "the wisdom of Allah," Sheikh explicitly said: "there is no creature that you see it and it is not the entity of God"; it is known from there that pronoun's referral in the phrase of "he is entity of God" is the God himself and nothing else (Ghesari, 2005: 193). Mir Syed Sharif Jorjani on the margin of the abstraction of Sheikh Tusi, by looking this saying of Sheikh, says: "and this is the later phase of the wisdom stage" (Hosseini Shahroudi, 2009: 130) and by these words, reveals his surprise against the speech of Sheikh. Of course, Ibn Arabi himself regards the understanding of Pantheism "beyond the further phase of wisdom stage. (Ibn Arabi, 1405, II: 289); (Ibid, Book IV: 279).

Now the "step beyond the stage of intellect" is explained and then the meaning of the word "entity" is investigated and "appearance" and "manifestation" will be defined after it.

\section{Stage beyond the stage of intellect}

The Root of " stage after intellect stage" can apparently be found from the late fifth century AD, and in the writings of the scholars such as Imam Muhammad al-Ghazali (d. 505), and after him Ainol Qudat Hamadani (525). "Is the interpretive step of Quran, says, "And God created you step by step and diversely" (14:71) and it means the realm, the religious faith is dependent on it"(Shafie Kadkani, 2014: 326) Ainol Qudat Hamadani, in the introduction says: "wisdom doesn't comprehend this point, if you have something beyond the intellect, you would understand what I say." (Ainol Qudat Hamadani, 1963: 283) So, the step beyond the specific wisdom stage is the comprehension of religious experience and wisdom and sense don't have way to it. Now two terms of 'Entity and Shown up' are explained by referring to the sayings of Sheikh.

\section{Entity}

The word "Entity" that misguided Simnani contains the meaning whose correct understanding exonerates Sheikh from the charge of polytheism making. If Ibn Arabi instead of the word "entity" would use the word "like/such as" in his work then he was worthy of invection; because he says: God has no Similitude as per the holy verse "nothing like him" and there is difference between Entity and Similitude, because the stages and privileges are reserved in the entity. The divine status of God requires that there is no analogous existence among the individual essences, moreover, as the analogy is a rational and imaginary matter; undoubtedly, if analogy was correct and right thing it was not separate from the things for example where we say this is similar to that"(Ibn Arabi, 1405, Book II: 346) he clearly defines the entity: " "About the man we say that he is a 'talking animal' without doubt, in addition, Zed is not similar to Amr in terms of his face, but he is just like Amar in terms of his humanity, and he is not something else and while he is no other one in terms of his humanity, so he is not similar to him but like him. (Ibid: Book III: 346) and he further argues that the reality of humanity is not such that accepts discrimination, but it is the same in every human essence for its details, so there is no similitude to that human reality, and likewise, all facts are in this manner." "Certainly the reality of human nature is not partible, but it is a fact of human existence generality not in essence a part of man and therefore, there is no similitude and analogous for him, so entire facts of existence are in this manner" (Ibid: Book III: 346). Therefore, there is no similitude to the actual essence and God is creature's entity. Since, the principle that we return to in our inside, is Allah, "nothing like him, because what appears by him is nothing but this fact that "there is no similitude to him" because how to create a thing whose trait doesn't require to create? While his reality doesn't accept the sublimity of similitude, so inevitably, any individual essence does not accept similitude in the universe and in «"lo (except him) is not a reality that accepts the "similitude." And every being except the Lord is another similitude under its poverty and need to God i.e. the principle which we return back to it in our existence-Lord- is the principle that has no similar, therefore what appears by God undoubtedly, would not have any similitude and similar, so how it is possible that God creates something and has not granted his own characteristics to that creature? Thus the reality of God's existence doesn't accept similitude and similar, therefore each essence and existence in the universe must be individual and unique and there should be no similitude and analogous for him" (Ibid: Book III: 347) therefore, God has no similitude, creatures have some analogous that is their very poverty and need towards God, but they are similar to each other in terms of real essence. Therefore as the existence is general, God is the 
Creature's entity similar to creature but creature is not God's entity/similar to God. "There is no one like him", "he accompanies you/he is with you, everywhere and we don't say that we are with God" (Ibid: Book VII: 371).

Manifestations in the forms of "appearance" and their multiplicity (i.e. the forms) are dominant in the entity of unity and they have no existence, there is no more difficult problem in divine sciences than this issue, for that the possibilities by Almighty are not productive except for essence, since there is no existence except Almighty God and possibilities are living in inexistence" (Ibid: Book VII: 371). The entity of signifier is a subtle meaning. "And we are closer to you than yourself but you don't see"(Qur'an, Event: 85). Lord! We don't see you and even don't see the veils and curtains across, we are behind the curtains and you are closer than our jugular vein to us and closer to us than ourselves, and this proximity causes our lack of observation and one doesn't see him when observation relates to you, how we could see you while you are closer to us than we ourselves?" (Ibn Arabi, 1405, Book VII: 92)

Existence is circular as per the perspective of Ibn Arabi in a sense that the essence encircles it. The reason of this claim is the citation of "Bezels" which says: we have been accommodated in the embodiment/bond of God and God is clearly with us". Afifi describes the embodiment/bond and says: "we take embodiment/bond and specification under the meaning of appearance and non-manifest or the inner act of power which are two faces of existential truth" (Afifi, 2008: 274). And at different places he also explains the Bezels as encircling the existence. "When God consolidate His creation, and thus strengthened the order of his industry and made it to revolving, the existence appeared in continuous and joined form, God wanted to reopen and separate it so put a gap between heaven and earth and made them separated as he evidenced it: those two were tied up and we made them separate from each other (Quran, prophets: 30) (Ibn Arabi, 1405, II: 315). Existence is in the form of nested circles in which each circle gets perpetual blessing from the next circle and blesses its rare circle that is the very meaning of inward and outward. "And when circles appeared in continuous form, the first circle disappears that had created these circles such that it is neither identified nor perceived; hence it is said about each circle that it is observed and seen but concurrently does not witness it and this is the mystery in witness "(ibid: book XII: 191).

"If the creature's vision was not through the Lord or if the vision of God was not via creature, there was no vision and manifestation at all"(ibid: 323 )

The circumference maintains the point in terms of science while the point protects the circumference from the perspective of presence; therefore each of the two protected and regardant protectors are under-consideration, God says: "'And to see and to be seen (the Zodiac: 153)"If one of them says, I, the other says too, I"

"So O my Lord and O my Creature whom you are dying and living for"

(Ibn Arabi, 1405, XII: 191)

\section{Manifested}

Its root is 'to manifest' that is equal to manifestation in the theoretical gnosis of Ibn Arabi. "Manifesting, appearance, Tashan/willed, relation, effusion of light, emanation, perpetual blessing etc. are placed against the terms such as: non-manifest, hiddenness, occultation, defy, veil and covering" (Rahimian, 2013:132). Ibn Arabi employs the term of "perpetual blessing" used by Flutini as Synonymous to manifestation (Izutsu, 2014: 166). "Unlike the pantheism theory that is implicitly referred to in the works of Ibn Arabi, its manifestation and dimensions have been much discussed in it". (Rahimian, 2013, 132) Ibn Arabi regards manifestation equal to creation. "Therefore, manifestation comprises of God's appearance in the form of other things. And if the manifestation and appearance was not God, the essence of things had never become evident," "And the Lord said: anytime we want something to be that thing immediately becomes existent." (Ibn Arabi, 1405, XII: 194) God has different manifestations and the word of manifestation is most common word used by Ibn Arabi that has a special meaning at every place. Including; the creation manifestation, inside manifestation, God's manifestation in every action and.... "Manifestation is the central point of Ibn Arabi's thought by which he achieves a precious Creative/Genetic system. Manifestation is a process in which the God - which is absolutely unknown in itself emerges him in more objective ways "(Izutsu, 2014, 166). "The form of essences is the God himself, in a sense that every manifestation of him is absolutely the same essence. If we say that each manifestation is the non-essential manifestations, is meaningless because there is no existence of other "(Afifi, 2008: 167). Therefore, based on the ontology of Ibn Arabi, the essence that in fact is single at the same time has different manifestations and these manifestations have no existential separateness from reality and the objectivity relation lies among them. In a general division "essence is divided into essence and essence manifestation: essence consists of the unknown being that is not recognizable and doesn't need any universe while the essence manifestation comprises of the same essence that has been appeared in the garb of its manifestation and watching his manifestation. Their relationship is like the relations between appearance and manifestation where this is a relationship of objectivity 
between them i.e. they have no existential separateness from each other. So as much as we perceive there is only the God existence that has appeared in the individual essence of possibilities."(Imdadgar, 2011: 187) based on it the essence is surrounded and encircled in which the existents are manifested particle wise in the nested circles.

\section{Other reasons of Ibn Arabi to prove Pantheism}

Ibn Arabi has other reasons to prove the pantheism that include:

\section{Time}

Time is not discussable in the 'Next world/Eternal world.' Considering the matter of time lack in the heaven, many discussions are settled about it and the pantheism. Ibn Arabi in this context says: "equality of effect with its cause is not necessary at all levels so the cause no doubt, has precedence and priority to its effect due to position. Whether this precedence and priority are science and knowledge or the essence of Exalted God, and the time's gap and amount are not reasoned between Necessary being inwardly and possibly, since our speech is on the first possible existent while the time itself includes possibilities, since if time is not an existential matter but a relationship, in this case the relation gets intellectual contingency and not the existential contingency with effect's existent contingency and because the time's gap is not reasoned between the necessary being and creature, therefore nothing is left except status/position, therefore it is not allowed that creature constantly occupy the place and position of Lord, as it is not allowed too, the effect permanently get the place of cause- in terms that it is the effect and effusion of it." (Ibn Arabi, 1405, Book III, 181).

\section{World is the face of God}

Ibn Arabi says world is the face of God and everything is destroyed but the face of God. There is only God and he is not mortal (Ibid: Book IV: 228). "So survival is at work after death, survival of the forms of existents' essence in their own limits and realities" (Afifi, 2008: 328).

\section{Nothing is void of Existence}

Mullah Sadra said while explaining the Pantheism: the essence surrounds and nothing is empty of essence because it is infinite. "The essence of almighty God is infinite and real non-composite, and the infinite essence leaves no opportunity for other entity across its width or length; otherwise that other for that infinite essence was as a "limit," So, there is not another essence other than the infinite essence of God, "(Rahimian, 2013: 129).

\section{Does Pantheism negate the Authority?}

The pantheistic thinking is dominant across entire 'Mystical unveilings' and 'Bezels', the interpretations of Sheikh are based on his pantheistic vision, he worships almighty God and calls him the ruler and obedient: "I thank him, thank to that who knows him-glorified and High exalted who is the sublime and lofty in attributes and great and bright in nature, the veil of grace covers his curtain and the window of Halt closes against the wisdom of his essence, if he addressed his slave/believer, he himself listens and speaks and what he commanded to perform, he is himself ruler and obedient to it" (Ibn Arabi, 1405, Book I: 54).

Ibn Arabi is stunned against the theory of pantheism, "and as this reality wandered me, according to the rule and right way, I composed the following:

"God is God and servant is also God,

Would that I knew who should carry out the duty?

If I say the servant is functionary, how can I say? He is not more than a dead body

If you say the God is appointed to conduct the duty,

In this case, how Almighty Lord is functionary to carry out the duty." (Ibid: Book I: 42)

At this point Abul Aa'la Afifi shouts and accuses Sheikh of compulsion and says: "Ibn Arabi under this rough compulsion struggles with twitches" (Afifi, 42: 2008) Sheikh perhaps suffers a kind of determinism but no doubt Pantheism is not rejecting the authority, existence is circular in view of Ibn Arabi. Mohi-ud-Din has clearly pointed out in individual essence. In this manner the Seven saints gain perpetual blessing from Saint, Saint from Pious, Pious from Pillar, Pillar from Chief/Captain, Captain from Pole or Succor gains emanation. "Ali Hajveri knows the Sainthood with stages that is divisible from top to bottom; that is divided as follows: four Saints who are called Pillars/Supports. Three Saints who are named Captain/chief. One saint who is called Axis or Pole. This group doesn't realize each other but needy of each other's permission in affairs that is orated and narrated in this news". (Hajviri 2011: 321; Sajjadi, 1992: 793) Ibn Arabi recognizes the move and ebullition in the universe, premiere-ness of the station of generation and station of change as well as perfection that all human beings have been created to achieve this status; thus moving towards sublimity can be seen in his theory. 


\section{Motion and Ebullition in existence}

Existence is in constant motion as per the perspective of Ibn Arabi. Motion rejects inertia and stagnation. Every entity has a worthy movement. "Verily, everything in the universe is under the state of motion or transforms from one state to other. Therefore the universe is time and in any time, it is evolution and transfer" and this concept was not stated by him for the first time because we see Attar in several occasions in his works has had a deep attention to the method that is working in the universe system. Attar in the first article of Asrarnameh, has an appreciating address to the status of man and calls him for the sublimation of soul and says: "the entire universe is in evolutional voyage, spheres and heavens are under persistent motion".

1-Numerous secrets unveil from each particle-if thy insight could see with open eyes.

2-You cannot see but this is your way-All revolve but you continue your way

(Attar, 2010: 142)

Shafiei Kadkani about the word of 'method' and the history of this thinking says: "to go and permanent motion is called method and before Attar, in the Persian poem, such comprehension was certainly inexperienced and this is difficult to rule that in the thoughts of mystic leaders/Sufi figures including Bayazid, Kherghani, Busaeed, Nouri, Hakim Termizi and others like him whether such inclusive look was present under the chapter of essential motion or not? Apparently, none of the ancient figures, before Attar, have spoken on the matter of essential motion and process of universe and transformation of similitudes, deposition and confusion and... "(Attar Nishabouri, 212: 1388)

Although Sanaei can also be considered as one of those who believe the motion in universe because he addresses the almighty Allah in the preface of his 'Hadigheh' in this way:

Disbelief and polytheism moving on the path of Almighty lord-Repeating the slogan, No one shares his territory.

(Sanaei Ghaznavi, 1982:60)

Motion is continue across the entire existence and it is not specific solely to the believers as Sheikh not only knows all believers but also disbelievers on the path of progress and ascension. (Ibn Arabi, 1405, Book III: 112). "Ibn Arabi considers all movements as love (oriented) motions, though apparently attributes them to other causes and reasons, he also regards the descending arch of essence as the result of love based motion "(Yasrebi, 2013: 436) he also looks the essence in motion and ascension and adds: the almighty God concurrently when he is at work every day, he is like an invariant that is un-needy of all creatures in exuberance." (Ibn Arabi, 1405, XII: 83) despite the universe is in ebullition and dynamism but concurrently it is supposed as motionless and stationary." Since the manifestation is shaped in a way that the second wave starts before the rising of first wave, this process as a whole leads to one thing that is the stable and everlasting nature" (Ibid., II: 168) So the existence is in permanent manner and motion that is in bustle and movement.

6-2-Change of state is higher than Fixity: Ibn Arabi places the change of state at a higher stage than the fixity and argued that the stage of change of state is more dynamic than the fixity stage. Change of state includes the shift of servant in his circumstances and this stage is a lower/inferior stage from the perspective of majority of Gnostics but in our view it is the most perfect stage and the condition of believer at this stage is as per the divine saying: "Everyday God is busy in doing something" (Ibid., book II: 10) Existence will remain in eternal and permanent ebullition and every world has its worthy motion. "The world of breaths, in every breath at every moment, the world is the place of manifestation in each of the manifestations, and the reason of this speech is the God's saying: he is engaged in worthy and important work every day. And everyone in his life feels diversity of inspiration in his heart, in his all motions and in his all actions, there is no movement and evolution in the eternal world or the mortal world but it is originated from the glory and blessing of almighty Allah. . Therefore, reliance upon it appears from that manifestation and disclosure and, of course, equal to what is granted to him. "(Ibid: Book III: 51)

6-3- God created men for perfection: Mohi-ud-Din believes there is nothing in the universe other than the truth and moderation and failure is accidental and perfection is inherent principle as a result, the access to perfection is possible for every human being and if man does not achieve perfection rank, he gets the humanity title to the extent he has to perfection (ibid., Book VII: 74). Based on the above instances, Ibn Arabi is not fatalist.

\section{Some results obtained from the belief in Pantheism}

\section{Best system}

From the perspective of Ibn Arabi God is the essence entity, so this essence is pure Good "The God who punishes and rewards, he has appeared with his mercy in all things, and the essence is absolutism"(Afifi, 2008: 
398).God is unveiled with the attributes of introduced matters whether praised or cursed as well the creature is manifested by the attributes of God." (Ibn Arabi, 1405, Book VII: 109). The theory of best system also has a history before Ibn Arabi that is attributed to Imam Muhammad al-Ghazali (450-505) in the fifth century who said: "there is nothing more surprising than that exists in the world" (Dehkhoda, 1974: 79) Ayn al-Quzat Hamadani says: "These impediments happen to you that you scale the divine acts at the specific balance of intellect. It means that a scholar writes a prominent book of science and his one year old baby protest against him that this book what to do with the job you are engaged in?" (Ayn al-Quzat Hamadani, Bita.: Volume 1: 345) as Sanaei and Attar say:

If you are good don't see ugly with ignominy- See-that in this world peacock engages in fly's job.

(Sanaei Ghaznavi, 1982:60)

Any impression we embossed on desert-we embossed it pretty you to see it elegant.

(Attar Nishabouri, 1980: 492)

Sheikh Shabestary who is similar to Sheikh Mohi-ud-Din says:

The world is like hair, mole and eyebrow-Everything is good at its proper place.

(Shabestary, 1972:84)

\section{Relation (attachment) of God with Creature}

The first treasurer of God's generosity is the generosity of God that appears by him in view of the hierarchy of "essence of appearance exists in his own entity, because all commandments appear from the negation, affirmation, incumbency, possibility and reduction (refusal)-and existence and non-existence and non-all of them are not happened and not allowed as well, but by an existent whose entity and nature are its essence, and his existence doesn't accept the multiplicity but by an existent whose entity and nature are its essence, and his existence doesn't accept the multiplicity due to his command over him, since the realities which are disclosed for him (for essence) in his own is because of his own essence. So we believe in multiplicity in the entity of that essence and that is single and every reality has a name, so he holds some names." (Ibn Arabi, 1405, Book VII, 188): And this expression negates their statement that said Sheikh believes creation is fantasy and fiction; martyr Motahari says those who say in this manner, are those who deny the immediate perceptions. (Motahari, 1991, Volume 1: 213) Ibn Arabi sets originality for the appearance of existents from the term that it is the other side of coin, the originality that is in its entity.

"My names emerged and I was multiplied and no one saw me, so I'm the real seer, $\mathrm{O}^{\prime}$ the one who says, is there anybody except him, so where is that you say? And anywhere if there is some other one, I am standing against him, God is mightier than all that exists and there is no one there except God, so swear to God if there was no God there was no concept of poverty and exuberance" (Ibn Arabi, 1405, II, 188).

Gnostics before Mohi-ud-Din consider the existents as mirage which is not original as Attar says; the Prophet of Islam (PBUH) was out of his essence when ascended:

$\checkmark$ Don't ask me what I detected in him-he was something different he sounded.

(Attar Nishabouri, 2010: 89)

If this couplet was composed by Mohi-ud-Din he would compose it in other way and he would say by referring to its existential stages: the Prophet of Islam (PBUH) received its outward as expressed in tradition that God created Adam to his own shape." Because in his intellectual system there is a sole essence that is Creation's entity and the relationship between God and creature is the relation between appearance and manifestation or appearance and non-manifest.

Mystics before Mohi-ud-Din don't give credit to strangers - except the God - and in contrary Ibn Arabi says: God is the very creation. In other words, in pantheism we face two propositions:

1- Essence is exclusive for God.

2- What is the relation of individual essence and possibilities with God? Is the shadow illusory, false and/or are original because they are debtor to essence?

Both pre and post Gnostics groups of Mohi-ud-Din believe in the exclusiveness of God as expressed by Maulana:

1 -from the beginning you guide to pray-finally you give reward for praying

2-first and last you are but we on the middle- nothing should come in the expression. 
(Maulavi, 1958-42, vol. 4, couplet 3999)

3-Our couplet is like the center of unity-everything is polytheist except oneness.

(Ibid, vol.6: couplet 1528)

And the difference lies in expressing the second proposition that whether creation/creature is illusory or it is a reality? Pre Mohi-ud-Din Gnostic poets say whatever exists is God and not the possibilities and they are non-existents. However, Ibn Arabi believes that as the existence is exclusive to God, each existent that gets essence from the source of perpetual blessing is also God. The relation that lies between God and creature is a divine/godly breath as Mohi-ud-Din interprets. "And that is the very divinely breath and spirit of God and the forms of existence have been flourished in that breathe because the breath and soul of God include all forms of creatures in the universe as the existence and breath of human being potentially contain all words and letters that are published by his existence" (Ibn Arabi, 1366: 124). However, these two methods are conceptually not very different but caused the development of two different views that ends into two different spiritual paths. In the first method i.e. the Khorasan gnosis the imaginary existence has to disappear that is secured by struggle against self-red death, while in the second method the seeker must achieve the existential wisdom and the starting way of it is provided by learning, discussing and intellect, to carry the seeker to mortality, at this stage he finds the delicate pointer of pantheism to entity. Ibn Arabi considers the taste perception of pantheism a position that is called vision stage that is the very stage of mortality." (Afifi, 2008:247) that is why he considers the self-wisdom preferred to the wisdom of Lord. "And self-knowledge of man is prior to his divinity/theology."(Ibn Arabi, 1366: 123). While Ibn al-Sarraj (d. 929 AD) says: "your existence is sin itself" (Schimmel, 1996: 254). Or the expression of Junaid when he said, "God is more acknowledged by inexistence rather his existence" (ibid, 1996: 322) So, some kind of difference in the mystical journey is seen in two schools of Khorasan Sufism and the mysticism of Mohi-ud-Din.

In expressing the Gnostics of mystical school of Khorasan, existence is equal to sensuality and the expression of Ibn Arabi is of a different kind. He considers the existence as the only reason of servant's originality. That is how we are dealing with two different mystical styles. That can be divided as pre and post Mohi-ud-Din gnosis; close to that what they say the mystical style of Khorasan and the mystical style of Iraq, the style that makes Mohi-ud-Din a distinguished figure of it. In other words, the mystical style of Khorasan is to leave the self or inward that in this migration, the seeker achieves the proximity of God while in the mystics of Ibn Arabi, the goal of conduct is to reach the point of knowledge on which the seeker realizes this delicate pointer by conscience vision that God is the creation entity and not dichotomy or dualism; because "anyone who recognizes himself has acquainted his God. So, the seeker is not taken out of his self, yet comprehends the mystery of unity by recognizing the depth of his existence and then he looks the God and creature like two sides of a coin the speech that Mohi-ud-Din much depends upon it. Know yourself to know the God. In fact, perceiving the pantheism or in other words self-knowledge, in the gnosis of Ibn Arabi is the goal of Sufism's spiritual journey. The Seeker of God at the beginning of the mystical journey of self-knowledge and following that has no knowledge of God and at the end of mystic journey finds the knowledge of self and realizes that he is nothing except God" (Shajari, 2011: 130).

Ibn Arabi considers the creature God's entity. If he in some parts of the "mystical unveilings" regards the world illusion, the concept of imagination in his intellectual system is more extensive and multi-faceted as compared to what Attar and Sanaei think. He says: so if you say God has a face you are right; since that face is a manifestation of God's manifestations as well as one of his manifestations. If you say that face is not for Lord but is other thing, you have interpreted it as the face seen in a dream is interpreted "(Afifi, 2004: 128). Including "what appeared and happened to Mary was nothing but depicted by her mind" (ibid: 236). In addition, the appearance or revelation of the Angel Gabriel to the Prophet (PBUH) was nothing but a picture, sketched in the imagination of Prophet (PBUH) (ibid: 147). In his view, the isthmus is a dream in relation to the mortal world and any other stage that is below the level of other stage is an imagination in relation to that stage and this is the very meaning of inward and outward. "Imagination is the base to all worlds. Don't you see the Prophet has considered this tangible life as an imagination and said people are asleep, so the root of all worlds is imagination and any nation living in any world is restricted to that imagination; for instance, the people of world are restricted to living or their own resurrection, the people of isthmus are also sleeping, but their sleep is lighter, the people of resurrection are too asleep because they are engaged in calculation and computation, same are those inhabiting in paradise or hell." (Jelly, 1970: 40-46) 


\section{Difference between God and Creature}

Ibn Arabi acknowledges the distinction between the God's and creature's right and says: "The world successively is at the stage of self-possibility whether inexistent or existent, and the almighty Allah is also contiguously to his own self in his essence stage whether it is common or even not existing, because if the world enters the necessity by-itself the timeless eternity of world and its equivalence at this stage with Necessary being that is "Allah", becomes obligatory so did not enter and for this reason difference and separation is placed between the God and Creature" (Ibn Arabi, 1405, book III: 181). Somewhere else he added: "God in his manifestation is the entity of everything and one with it; however he has no union and unity with the essence of objects but he is the hidden identity and objects are nothing but have their own (i.e. Outward nature)" (Ibid, book III, 238). This is worth mentioning, that in view of Ibn Arabi, the thingness of the things is not existential and not subsisting. And relying on the same view he expresses the contingency of the world and says: "the existence of world is not related to essence of God but it is relevant to the relations. Therefore, the world is not equal to Almighty God in existence." (Ibid: book III, 220) and the example that he expresses in this regard: "like the moon with sun in the light that appears in the moon, the light that is in the moon is nothing other than the sun; likewise, the existence that is true for possibilities is nothing but the essence of God." "But existence is the entity of that single essence and that single essence is the very multiple entities."(Afifi, 2008:109) and as per his saying: "in fact, there is no similar and similitude existence, existence is a single reality and nothing will be opposite to it." (Afifi, 1999: 92) Ibn Arabi says universe is the appearance of God "and no appearance is for something whose identity doesn't resemble to that thing, so anyone whose existence is like this, how can accept ascription or binding?" (Ibid: 267) Ibn Arabi knows his pantheism the entity of monotheism and belief and believes in some way that the one who doesn't believe the unity he considers this individual is suffering from some kind of polytheism. He establishes a close relation between entity and appearance. In fact world is the appearance of God i.e. world is the perpetual blessing of God that is not restricted to today or yesterday but it is a perpetual blessing that is continuous without interruption. In this manner we can say: "the pre Ibn Arabi gnosis is the gnosis or mysticism of Khorasan because the origin of the initial thoughts and the very first elders of this spiritual current is the great Khorasan but after the emergence of Ibn Arabi the mysticism of Khorasan is marginalized gradually and the style of artistic look of Ibn Arabi in relation to religion, gets the dominant aspect" (Shafiei Kadkani, 2014: 547) and this is nothing except the comprehensiveness of his type of look to gnosis and periodization indicated before. In the pantheistic school of mysticism of Mohi-ud-Din, essence is the pyramidal circle that lies on the summit of unity and the existential circles continue in the lower stages where the objectivity relation-manifestation or the inward or outward are dominant among them. Nothing is void of existence so it is the entity of him that manifests like particle. In other words, as all locate in the existence therefore they are his entity.

\section{Result/Conclusion}

The research achieved the following results:

> Unity or mystical unity in Iranian Islamic gnosis, especially in the mystical literature of Iran has been detected in the form of unity, visionary unity and mystical conduct or journey as well as the relation of God with creation/creature and the theme of unity has had the visionary base from the third century to the time of Ibn Arabi that became famous under the gnosis of Khorasani school.

$>$ The Iranian Islamic mysticism has generally been assessed as a move to get to the sole reality or the very mystical unity.

$>$ Mystical unity can be assessed based on the sayings and the life of prophet (PBUH) as well as the mystic journey of Gnostics.

Mystical unity in the school of Khorasan from second century onwards has gone ahead in a manner that during seventh century it led to the emergence of theoretical gnosis of Ibn Arabi and propounding the significant issue of existence transcendental unity or the particular unity of existence. The theory that was propounded by Ibn Arabi.

$>$ The gnosis of Sheikh Mohi-ud-Din from the visionary viewpoint has similarities with the Gnostics' vision of his predecessors that led to the consideration of Monotheism of Attar, Maulana and Sanaei etc. from pantheism type of Ibn Arabi by some figures, while Ibn Arabi established the monotheism in the form of a very accurate system based on the pantheism that is specific to him and his post Gnostics all are influenced by him.

$>\quad$ The outcome of these two views - Khorasan gnosis and the school of Mohi-ud-Din - have led or resulted into two different ways of mystical journeys/conducts while in the Khorasan gnosis the base of conduct is to struggle against self, whereas in the school of Mohi-ud-Din the root of mystical journey is based on the 
Knowledge of self. The mysticism of Mohi-ud-Din is to formulate a kind of ontology that is nothing other than the existence from the viewpoint of Ibn Arabi and God is the entity of creation. Existence is circular, nested or interconnected, exoteric and esoteric, its outward is creature and inward is God i.e. the existence that is equal to God, stable and constant in ebullition and motion and no fixed point is found in it and this meaning and concept "God is busy in some work every day" and further interpretation on the verse " "The hand of God's power is mightier than all-authorities." In other words, he considers the existence exclusively in the essence of Almighty Lord that is God as well as creation and also one and single, at the same time multiple. He is eternal as well creatable, the first and the last, exoteric and esoteric. Ibn Arabi calls the creature as the right of creation in a dual relation; relationship between God and the world the relation of objectivity based on the appearance and non-manifest. In addition, the pantheism that he expresses is not similar to that was appeared in the works of predecessor Gnostics. He announces somewhere in his "Bezels" and "Mystical unveilings" "Glorified and Pure is the God who revealed things, while he is himself their entity." We are talking about the word "Entity" that means the essence and root or origin and from this viewpoint it has become closed to the originality of existence and considers the God and Creation as two sides of a coin. The axis of his pantheism is poverty and manifestation and considers the spiritual wealth specific to Oneness of God that is enough. So, in the intellectual system of Ibn Arabi God is that sole that is under permeation in the world that is the entity of creation and there is no difference between them except the difference of divine essence and their multiplicity as a result of forms and relations. Undoubtedly, the speech of great Sheikh is that: unity is the whole existence and nothing; there is no effect of duality of Creator and Creature and if the intellect is unveiled the whole is seen in one, like the One that is whole of the wholes.

\section{References}

Afifi, A. (1988). Comments on Bezels of wisdom for great Sheikh. Mohi-ud-Din Arabi, Tehran: Azzahra publication.

Afifi, A. (1988). Comments on Bezels of wisdom. Tehran: Azzahra publication-first issue.

Afifi, A. (2008). an account to the Bezels of wisdom of great Sheikh Mohi-ud-Din Arabi. translation: Nasrollah Hekmat, Tehran: Elham publication, second edition.

Akrami and Hemmati, Mir Jalil and Zulfikar. (2011). "Pantheism and the unity of religions", Seasonal of Literature and Human Sciences specialist for research on Rumi, Azerbaijan: Year 4, Issue 9, winter, pp. 81-106.

Ansari, K. A. (1941). "Thesis" Correction: Tabendi Gonabadi, Tehran, Armaghan publication.

Ansari, K. A. (1984) "classes of Sufis" Correction: Mohammad Sarwar Molaei, Tehran: Tousi publication.

Ansari, K. A. (1993). "Way stations of the travelers" an account to: Afif Suleiman Telemecani, Qum, Bidar publication.

Asfrayny, Nurr-uddin, Abdul Rahman. (1980). "Detector of secrets" research: Hersal Lendat, Tehran: McGill Institute: Tehran Branch .

Ashtiani, S. J.(2002). An account to "Bezels of Wisdom" by Ghesari" Qum: Boustan Publication, Fifth Edition.

Attar Nishabouri, F. (1984). complete works of Attar. Correction: Taghi Tafazzoli, Tehran, scientific and cultural.

Attar Nishabouri, F. (1998). the conversation of Birds. Correction: Mohammad Reza Shafi'i Kadkani, Tehran, Sokhan publication.

Attar Nishabouri, F. (2010). mysterious book. Correction: Mohammad Reza Shafi'i Kadkani, Tehran, Sokhan publication, second edition.

Baghli Shirazi, Sheikh Ruzbehan. (1996). "an account to divinely inspired statements" Correction: Henry Corbin, Tehran, Tahouri publication.

Bahar, N. (2008). "The Mirror of knowledge", "Ibn Arabi and theory of pantheism", Tehran: vol., pp. 43-66 (10).

Bayar Nas, J. (2003). "Comprehensive history of religions", translated by Ali Asghar Hekmat, Tehran, Scientific and Cultural Organization.

Bertles, Yogini, Edward Yewich. (1978). "Sufism and Sufi literature", translation Sirous Izadi, Tehran, Amir Kabir Publication.

Bukhari, M., Ibrahim, A., \& Muhammad, I. (2005). An account to recognize the doctrine of mysticism. "Introduction and correction: Mohammad Roshan, Tehran: Asateer Publication, Second Edition. 
Dehkhoda, A. A. (1974). Adage. Tehran: Amir Kabir publication.

Ghesari, D. (2005). An account to Bezels of wisdom. Research: Hassan Hassan Hassanzadeh Amolie, Qum: Boustan Ketab publication.

Hajvery, Abolhasan Ali bin Osman. (2011). "detection of invisible" Introduction correction and comments by: Mahmoud Abedi, Tehran: Soroush publications.

Hallaj, Hussein ibn Mansur. (1912). The book of Altvasin. Paris: Louis Massignon publication.

Hamadani, Aenol Qudat but the Chief. (1963). "preparations and research by": Afif Asiri, Tehran: Tehran University.

Hamadani, Aenol Qudat. (Beata). "letters of Aenol Qudat" Correction: Afif Asiran and Ali Naqi Monzavi, Tehran: Culture Foundation of Iran.

Hosseini Shahroudi, Syed Morteza. (1999). Article of Comparative Study on pantheism from the viewpoint of Ibn Arabi and Espinoza. Tehran: Journal of specialized university of Razavi Sciences (theology and law), (29), 129-160.

Ibn Arabi, Mohi-ud-Din (1405 AH), in "conquests of Mecca", 14 volume book, (first, second, third, fourth, fifth, seventh, twelfth journey) research and provision Dr. Othman Yahiya, issuance and referral: Dr. Othman Yahiya, issuance and referral: Ibrahim Madkour, Cairo: Arab publishing library.

Ibn Arabi, Mohi-ud-Din. (1988). "Bezels of Wisdom" Research: Abulola Afifi, Tehran, Almktaba-tozzahra publication, $1^{\text {st }}$ edition.

Imdad, T. (2011). Ontology principles in Sufism of Ibn Arabi. Research-Scientific Seasonal Journal - Qum, 3 and 4, 175-195.

Izutsu, T. (2014). "Sufism and Taoism" Translation: Mohammad Javad Gohari, Tehran: Rouzaneh publication, Fifth Edition.

Jahangiri, M. (2005). Mohi-ud-Din Ibn Arabi Mystics' leading figure of Islamic gnosis. Tehran: Tehran University.

Jalili, A. K. (1970). perfect man in the initial and last knowledge. Egypt: Cairo.

Javadi Amolie, A. (2007). "sealed nectar" vol. 10, Qum, Asra publication.

Kadkani, S. (2014). Poetical language in Sufi prose. Tehran: Sokhan Publication.

Kakaei, G. (2013). pantheism as narrated by Ibn Arabi and Meister Eckhart. Tehran: Hermes, Fifth Edition.

Maulavi, Jalal al-Din Muhammad. (1975). "spiritual couplets" efforts and correction by: Reynolds Elaine Nicholson, Tehran: Amir Kabir.

Maulavi, Jalal al-Din. (1336-1342). Complete works of Shams. correction and margins: Badi'ozaman Foruzanfar, Tehran: University of Tehran.

Motahari, M. (1991). an account to expanded epopee. Tehran: Hekmat publication.

Movahhed, Mohammad Ali, Samad. (2011). Bezels of wisdom. Tehran: Karnameh publication, Fourth Edition.

Rahimian, S. (2013). Foundations of theoretical Mysticism. Tehran: Samt publishing co., Fifth Edition.

Reiter, H. (2010). "life Sea" translation: Abbas Zaryab, two volumes, Hoda International Publications.

Roodgar, M. J. (2011). Pantheism from revelation looks. research-scientific Journal of Islamic Sciences, IV year, Issue 20, pp.111-132.

Sajadi, S. J. (1992). nomenclature and mystical interpretations. Tehran: Tahoori library.

Sanaei Ghaznavi, M. B. A. (1970). "Garden of truth" Correction: Professor Razavi, Tehran: Tehran University.

Sanaei Ghaznavi, M. B. A. (1976). "Complete works of Sanaei" effort: Professor Razavi, Tehran: Sanaei library.

Schimmel, A. (1374). Dimensions of Islamic Mysticism. Tehran, office of the Islamic culture publication.

Shabestary, M. (1972). "Mysterious Garden" effort by: Ghorban Ali Mohammad Zadeh and Hamid Mohammad Zadeh, Baku.

Shajari, M. (2011). "Goal of mystical journey and conduct from the viewpoint of Ibn Arabi" mystical studies, Kashan: Faculty of Humanities, spring and summer issue, pp. 115-144.

Siraj al-Tusi, A. N. (1960). Shine of mysticism. Research: Taha Abdul Karim Mahmoud Abdul Baqi Sarvar, 
Cairo: National Library of Modern books, Egypt and Baghdad: Office of Muthanna.

Souzanchi, H. (2005). "Pantheism in the transcendent knowledge, historical and semantic study," Journal of Philosophy of Religion (book of philosophy), Tehran: Year One, Volume 2, Issue 2, pp. 133-1166.

States, T. (1357). mysticism and philosophy. Translation: Bahaoddini khorramshahi, Tehran: Soroush publication. Yasrebi, Syed Yahiya. (1391). "theoretical gnosis" Qum: Institute of Boustan Ketab, Eighth Edition.

\section{Copyrights}

Copyright for this article is retained by the author(s), with first publication rights granted to the journal.

This is an open-access article distributed under the terms and conditions of the Creative Commons Attribution license (http://creativecommons.org/licenses/by/3.0/). 